\title{
Waste Management in Cassava Processing Mill Industry in Kwale, Niger Delta, Nigeria
}

\author{
Peter M. Eguvbe ${ }^{1}$, Salem Azagbaesuweli ${ }^{2}$, Joy O. Obielumani ${ }^{3}$, and Edith A. Enemose ${ }^{4}$ \\ $1 \& 2$ Department of Environmental Science and Resource Management, National Open University of Nigeria, 14-16 Ahmadu Bello \\ Way, Victoria Island, Lagos, Nigeria (Emevor Community Study Centre). \\ ${ }^{3}$ Department of Chemistry, Federal College of Education (Technical), Asaba, Delta State, Nigeria \\ ${ }^{4}$ Department of Chemistry, Nigeria Maritime University, Okerenkoko
}

\begin{abstract}
Background and Objective: Kwale is one of the major cities in the Niger Delta Nigeria, that is a major producer and processor of cassava. This study investigated the waste management practice that is adopted by cassava processors in kwale in the Niger Delta, Nigeria. Materials and Methods: The six quarters dominant in processing cassava were selected for the study. The survey involved the application of a well structured questionnaire which was administered to cassava processors of the selected quarters, which includes 30 male and 30 female respondents. The frequency distribution tables/percentages and descriptive statistical method was used for data analysis. Results: Results from the analysis revealed that the major products of cassava are Garri $(50 \%)$ and Fufu $(50 \%)$. It also revealed that cassava peels, cassava sieveates, cassava wastewater and starch content constitute $100 \%$ of the wastes produced and the different disposal methods adopted by cassava processors. Results showed that $100 \%$ of the respondents are aware of the negative impact of cassava waste on the environment. Conclusion: The findings also showed that the cassava wastes generated can be converted to secondary beneficiary products. The study therefore recommends proper management of cassava wastes.

Keywords: Cassava processing mill, waste management, cassava processors, environmental pollution, cassava wastes
\end{abstract}

\section{INTRODUCTION}

$\mathrm{K}$ wale is one of the major cities in the Niger Delta, Nigeria, which is a major producer and processor of cassava $^{1}$. Kwale and its environs are located with several cassava processors which require adequate cassava waste management to avoid pollution hazards, degradation of the environment and also convert cassava wastes into secondary products for use by man, industries and farm animals.

Today, there is a worldwide concern for healthy environment in our cities and towns. Environmental pollution caused by poor waste management has become the order of the day. Agricultural, industrial and municipal wastes have been on the increase in Nigeria for the past decades ${ }^{2}$. Agricultural products such as "Cassava" (ManihotesculentaCrantz), have been noted to contribute so much waste to the environment in Nigeria.

Nigeria is involved in growing and production of so many food crops. One of such crops is cassava, a starchy staple food crop which is capable of resisting drought and disease. It also provides different job opportunities for both men and women from the production stage till it gets to the final stage.
According to Olukanniet al. ${ }^{3}$, Nigeria is the largest producer of cassava in the world. Nigeria being the biggest cassava processing nation produces so much wastes causing environmental pollution. Most cassava producers and processors in Nigeria are small scale farmers. Cassava provides a cheap source of carbohydrate to Nigerians that come in the form of garri, fufu, flour, starch, tapioca, cassava chips etc. The processing of cassava starts with the peeling of the bark of the tuber. If the tubers are for the making of garri, they are sent to the mills for grating, pressing, sieving and frying. But if the tubers are for fufu, they are fermented and sieved in water and allowed to settle.

Cassava processing generates solid and liquid residues that are harmful to the environment. The two significant biological wastes that may cause damage to the environment are derived during cassava processing and they are the cassava peels and the liquid effluent squeezed out of the fermented parenchyma mash.

Cassava wastes can be grouped into; Cassava peels, which are obtained after the tubers have been water-cleansed and peeled mechanically ${ }^{4}$; Cassava offals (got after fufu extraction); Starch (got from pressing grated cassava); Cassava waste water (a acidic and poisonous water); and Cassava sieveates (obtained fresh after sieving grated and dried cassava and after frying garri).

The cost associated with the handling and disposal of these wastes constitute a huge financial burden to cassava processing industries in most rural regions of the country. As a result of this challenge, most rural cassava processors choose to dispose the cassava processing wastes generated into the environment. These wastes have been identified to be harmful to the environment ${ }^{5}$.

The cassava wastes in most cases are not disposed of properly, constituting nuisance to the environment ${ }^{6}$. Individuals living near cassava mills or the dump sites of cassava wastes suffer foul odour, loss of animals due to intake of acidic cassava waste water as well as fish ponds pollution. Therefore with increased production of cassava in Nigeria, proper cassava waste management is inevitable and a must for cassava processors and the government. Apart from proper cassava waste disposal, it is important to consider the reuse or conversion of cassava wastes as feed stuffs or food (nutrient) 
supplements for farm animals and also for fish farming. According to Kehinde ${ }^{7}$ cassava wastes can be processed and converted into value added components such as methane, pork, ethanol e.t.c.

The city of Kwale and its environs are located with several cassava processors which demand proper cassava waste management to avoid pollution hazards, degradation of the environment and also convert cassava wastes into secondary products for use by humans, farm animals and industries.

A survey of the literature indicated that limited data are currently available on the waste management of cassava processing mill industry in the Niger Delta. The objectives of this study were: to determine the major products and types of cassava wastes obtained, to assess the methods of cassava wastes disposal and also to determine the negative impact of cassava wastes on the environment with a view to providing information on the conversion of cassava wastes to other secondary products beneficial to man and animals.

\section{MATERIALS AND METHODS}

\section{Study Area}

The study was carried out at Kwale community in the Niger Delta, Nigeria, from October 2019 to March 2020. The area is located approximately between Longitudes $6^{\circ} 43^{\prime}$ and $42.48^{\prime}$ East and Latitudes $6^{\circ} 11^{\prime}$ and $52.23^{\prime}$ North of the equator. The major occupations of the people are hunting, fishing, trading and farming. It is also the location of some lovely tourist attractions. The modes of transportation in this area include; canoes and boats (River and Sea transport), vehicles and tricycles (Road transport).

\section{Sampling Technique}

In this study the researcher made use of the systematic sampling method, the questionnaires.

The sample consisted of five (5) female and five (5) male in the cassava processing Mills. They were all selected randomly so as to ensure that the six quarters of kwale were covered.

\section{Instrument for Data Collection}

The instrument for data collection was a structured questionnaire, which contains 16 questions in all. These questions are divided into two sections.

\section{Validity of the Instrument}

The instrument was given to the supervisor and further research was still carried out. Their suggestions and observations were reflected and were employed as to obtain the final draft of the instruments hence, authenticating its validity.

\section{Reliability of the Instrument}

The test-retest reliability was adopted. It was used to determine the reliability of the questionnaires. 60 copies of the questionnaires were administered on 60 selected respondents comprising of 30 females and 30 male. After a period of two weeks another 60 copies of the same were re-administered on the same selected respondents. This was done to compare their responses to the questionnaires and note areas of conflicting responses and modify the questionnaires and to remove any form of ambiguity. The analysis of the data collected can be relied upon for future purpose in managing waste from cassava processing mill.

\section{Procedure for Data Collection}

The researcher collected data using the questionnaire. The questionnaires were personally administered by the researcher to the respondent. In some cases, the research questions were explained by the researcher to the non literate respondents. The questionnaires were divided into two sections: Section I comprises of the sex, age range, occupation (primary and secondary) and highest educational qualifications of the respondents working in the cassava processing mill. Section II is divided into 7 questions where it is sought to answer the 7 research questions.

\section{Data Analysis}

The answers to the research questions were analyzed using the frequency distribution tables/percentages and descriptive statistical method was applied. The percentage was calculated using this formula ${ }^{8}$

Simple percentage,

$\%=\frac{\mathrm{f}}{\mathrm{n}} \times \frac{100}{1}$

Where, $\mathrm{F}=$ frequency

$$
\begin{aligned}
& \mathrm{N}=\text { No of respondents } \\
& \%=\text { percentage }
\end{aligned}
$$

\section{RESULTS AND DISCUSSION}

\section{Major Products of Cassava Produced in Kwale}

From the analysis of data in Table 1 below, it was revealed that Garri, Fufu, starch, cassava Flour and tapioca are the five major products of cassava produced in kwale. From the table, conclusion can be drawn that $100 \%$ of Garri and $91.7 \%$ of Fufu are produced more by cassava processors in Kwale. The findings of the study are in agreement with the results of Kehinde $^{7}$ who posited that after petroleum, cassava is a major contributor of Nigeria's gross domestic product. They also stated that Cassava and its products are of high demand in Nigeria as the major supplier of energy to man. It can be shown that in Nigeria, Garri, Fufu, starch, cassava flour, tapioca and cassava chips are the major products produced from cassava. From the findings it can be concluded that in kwale cassava processors are divided into 5 categories of cassava producers. 
Table 1: Respondent's Percentage Response on the Major Products of Cassava Produced, and Reason for Producing More of the Products

\begin{tabular}{|c|c|c|c|c|c|c|c|}
\hline $\begin{array}{c}\text { S/ } \\
\mathrm{N}\end{array}$ & Items & $\begin{array}{c}\text { Mal } \\
\text { resp } \\
\text { onse }\end{array}$ & $\begin{array}{c}\text { Perce } \\
\text { ntage } \\
\%\end{array}$ & $\begin{array}{c}\text { Femal } \\
\text { e } \\
\text { respon } \\
\text { se }\end{array}$ & $\begin{array}{c}\text { Perc } \\
\text { enta } \\
\text { ge } \%\end{array}$ & $\begin{array}{c}\text { Tota } \\
1 \%\end{array}$ & $\begin{array}{c}\text { Reasons for } \\
\text { producing } \\
\text { more of the } \\
\text { product }\end{array}$ \\
\hline 1 & Garri & 30 & $50 \%$ & 30 & 50 & 100 & $\begin{array}{c}\text { Higher } \\
\text { demand }\end{array}$ \\
\hline 2 & Fufu & 25 & $\begin{array}{c}41.7 \\
\%\end{array}$ & 30 & 50 & 91.7 & $\begin{array}{c}\text { High } \\
\text { demand } \\
\text { and easy to } \\
\text { produce }\end{array}$ \\
\hline 3 & Starch & 10 & $\begin{array}{c}16.7 \\
\%\end{array}$ & 25 & 41.7 & 58.4 & $\begin{array}{c}\text { For } \\
\text { consumptio } \\
\mathrm{n}\end{array}$ \\
\hline 5 & $\begin{array}{c}\text { Cassava } \\
\text { flour }\end{array}$ & 15 & $25 \%$ & 25 & 41.7 & 66.7 & $\begin{array}{c}\text { Mainly for } \\
\text { consumptio } \\
\mathrm{n}\end{array}$ \\
\hline Tapioca & 5 & $8.3 \%$ & 5 & 8.3 & 16.6 & $\begin{array}{c}\text { Consumpti } \\
\text { on, perhaps } \\
\text { for sale }\end{array}$ \\
\hline
\end{tabular}

Source: Field Survey 2019

\section{Cassava Wastes Obtained after Getting Major Products}

As shown in Table 2, 100\% of the respondents identified cassava peels, cassava sieveates, cassava wastewater and starch content as the wastes obtained from cassava after getting their major products. $91.7 \%$ of the respondent agreed that unfermented cassava is also a cassava waste product after obtaining their major product. It can be deduced that cassava peels, cassava sieveates, cassava waste waters and starch content are common cassava waste product. This findings agree with Izahet al. ${ }^{9}$ who found out that the major cassava wastes are; cassava peelings, cassava mill effluents (Starch content and cassava waste water ) and cassava sieveates. From these findings, it can be deduced that cassava peelings, cassava mill effluents and cassava sieveates are the only waste products obtained from cassava. While unfermented cassava is a cassava waste obtained during fufu processing.

Table 2: Summary of Respondents Response on the Various Cassava Wastes.

\begin{tabular}{|c|c|c|c|c|c|c|}
\hline S/N & Items & $\begin{array}{c}\text { Male } \\
\text { response }\end{array}$ & $\%$ & $\begin{array}{c}\text { Female } \\
\text { response }\end{array}$ & $\%$ & Total \\
\hline 1 & $\begin{array}{c}\text { Cassava } \\
\text { peels }\end{array}$ & 30 & 50 & 30 & 50 & 100 \\
\hline 2 & $\begin{array}{c}\text { Cassava } \\
\text { sieveates }\end{array}$ & 30 & 50 & 30 & 50 & 100 \\
\hline 3 & $\begin{array}{c}\text { Cassava } \\
\text { wastewate } \\
\text { r }\end{array}$ & 30 & 50 & 30 & 50 & 100 \\
\hline 4 & $\begin{array}{c}\text { Starch } \\
\text { content }\end{array}$ & 30 & 50 & 30 & 50 & 100 \\
\hline 5 & $\begin{array}{c}\text { unferment } \\
\text { ed cassava }\end{array}$ & 25 & 41.7 & 30 & 50 & 91.7 \\
\hline
\end{tabular}

Source: Field Survey 2019

\section{Methods of Cassava Wastes Disposal in Kwale}

The analysis revealed that the different gender (male and female) of cassava processors have different ways of disposing cassava waste. From the findings in Table 3, it was shown that $33.3 \%$ of the male and $8.3 \%$ of female respondents used the "Bury method (pit) as a disposal method for cassava peels. While $8.3 \%$ male and $16.7 \%$ female respondents used the open dumping and $8.3 \%$ male and $25 \%$ female respondents do dry this cassava peel and sell to animal rearer. This findings agree with Olukanniet al. ${ }^{3}$ research carried out on waste management practice adopted by cassava processors in Ogun State Nigeria and also Jackson et $\mathrm{al}^{7}$ who observed that cassava peels can be dried and used as animal feeds. Odediran and Ojebiyi ${ }^{10}$.stated that, aside sun-drying of peels for feeding animals, majority of cassava processor were not aware of other forms of cassava peel utilization and explains why cassava peels were being disposed as waste by the majority of the cassava processors. Other methods of cassava peels utilization is not well known by these cassava processors. Cassava sieveates is usually ground and processed to garri as agreed by the respondents(100\%). $33.3 \%$ male and $41.7 \%$ female dispose cassava wastewater on the ground, While $16.7 \%$ male and $8.3 \%$ female dispose into a pit. $41.7 \%$ male and $33.3 \%$ female dispose starch content into a sewage pit or tank. While $8.3 \%$ male and $16.7 \%$ female process and sell for consumption or the use of gum. $25 \%$ male and $41.7 \%$ female dry and process unfermented cassava into new product (cassava Flour).While 25\% male and $8.3 \%$ female dispose this waste using the open dumping system. This findings also agree with the literature review on cassava wastes and waste management in Nigeria where it was stated that sieveates from fried garri can be ground and mixed with garri and cassava waste water and starch content can be restricted to sewage pit. Izah et al. ${ }^{9}$ noted that since Nigeria is the largest cassava processing nation, high amount of wastes need to be well managed and utilized to avoid negative impact on humans and the environment.

Table 3: Different Methods of Cassava Waste Disposal.

\begin{tabular}{|c|c|c|c|c|c|c|c|}
\hline $\mathrm{S} / \mathrm{N}$ & Items & $\begin{array}{c}\text { Method of } \\
\text { disposal }\end{array}$ & $\begin{array}{c}\text { Male } \\
\text { respo } \\
\text { nse }\end{array}$ & $\%$ & $\begin{array}{l}\text { Femal } \\
\mathrm{e} \\
\text { respon } \\
\text { se }\end{array}$ & $\%$ & Total \\
\hline \multirow[t]{3}{*}{1} & $\begin{array}{l}\text { Cassav } \\
\text { a peels }\end{array}$ & $\begin{array}{c}\text { Bury (in a } \\
\text { pit) }\end{array}$ & 20 & $\begin{array}{c}33.3 \\
\%\end{array}$ & 5 & 8.3 & 100 \\
\hline & & $\begin{array}{c}\text { Open } \\
\text { dumping }\end{array}$ & 5 & 8.3 & 10 & 16.7 & \\
\hline & & $\begin{array}{l}\text { Dry and } \\
\text { sell to } \\
\text { animal } \\
\text { rearer }\end{array}$ & 5 & 8.3 & 15 & 25 & \\
\hline 2 & $\begin{array}{l}\text { Cassav } \\
\text { a } \\
\text { sievates }\end{array}$ & $\begin{array}{l}\text { Reverse- } \\
\text { process to } \\
\text { garri } \\
\text { (Ground) }\end{array}$ & 30 & 50 & 30 & 50 & 100 \\
\hline \multirow[t]{2}{*}{3} & $\begin{array}{c}\text { Cassav } \\
\text { a waste } \\
\text { water }\end{array}$ & $\begin{array}{l}\text { Thrown on } \\
\text { the ground }\end{array}$ & 20 & 33.3 & 25 & 41.7 & \\
\hline & & $\begin{array}{l}\text { Disposed } \\
\text { into a pit }\end{array}$ & 10 & 16.7 & 5 & 8.3 & 100 \\
\hline \multirow[t]{2}{*}{4} & $\begin{array}{l}\text { Starch } \\
\text { content }\end{array}$ & $\begin{array}{c}\text { Disposed } \\
\text { into a } \\
\text { sewage } \\
\text { tank or pit }\end{array}$ & 25 & 41.7 & 20 & 33.3 & \\
\hline & & $\begin{array}{l}\text { Process } \\
\text { and sell }\end{array}$ & 5 & 8.3 & 10 & 16.7 & 100 \\
\hline 5 & $\begin{array}{c}\text { Unferm } \\
\text { ented }\end{array}$ & $\begin{array}{l}\text { Dried and } \\
\text { processed }\end{array}$ & 15 & 25 & 25 & 41.7 & \\
\hline
\end{tabular}




\begin{tabular}{|l|l|c|c|c|c|c|c|}
\hline & cassava & $\begin{array}{c}\text { into new } \\
\text { product }\end{array}$ & & & & & \\
\hline & & $\begin{array}{c}\text { Open } \\
\text { dumping }\end{array}$ & 15 & 25 & 5 & 8.3 & 100 \\
\hline
\end{tabular}

Source: Field Survey 2019

\section{Negative Impacts of Cassava Wastes on Kwale Environment}

Results gathered from respondents showed that cassava wastes have negative effects on the environment. Some of the negative impacts include: causes odor (foul smell), promotes mosquitoes causing typhous fever, and makes the environment dirty which attracts rodents, contamination of streams by improper disposal of cassava waste water and starch content which will not be safe for use. This finding agree with Burns et al. ${ }^{11}$ that cassava processing mills produces wastes that produce offensive odor and down grade a community's aesthetic status. Several studies by Alyson et $\mathrm{al}^{5}$ and Izah ${ }^{12}$ have also highlighted the offensive smell and soil degradation caused by cassava wastes. Izah et al. ${ }^{13}$ also investigated the effect of Cassava effluent in the environment and found out that the effluent had negative effects on plants, air, domestic animals, soil and water. Adeyemo ${ }^{14}$ also noted the negative impact of cassava waste water on fish rearing because of the cyanogenic contents. Cassava wastes contain highly polluting bio-materials which can affect the environment in different ways. The results are discomfort, anxiety, mosquito infestation and frequent illness ${ }^{15}$.

Table 4: Summary of Respondent's Response on the Negative Impact of Cassava Wastes

\begin{tabular}{|c|c|c|}
\hline Respondents & Responses (negative impact) & Total \% \\
\hline 60 & $\begin{array}{c}\text { Causes odor (foul smell) } \\
\text { Promotes mosquitoes causing typhous } \\
\text { fever. }\end{array}$ & Makes the environment dirty which \\
attracts rodent. & 100 \\
& $\begin{array}{c}\text { The cassava waste water and starch if } \\
\text { not properly disposed can flow into } \\
\text { streams which will not be safe for use }\end{array}$ & \\
\hline
\end{tabular}

Source: Field Survey 2019.

From Table 4, it shows that cassava waste has a negative impact on kwale environment, as agreed by $100 \%$ of the respondents.

\section{Conversion of Cassava Wastes to other Secondary Products} Beneficial to Man and Animals

From the findings in Table 5, it was revealed that $50 \%$ of the respondents are not making effort. While 50\% are making effort in converting cassava waste to beneficiary products. It was shown that cassava peels can be converted to feed supplement for animals. Alyson et $\mathrm{al}^{5}$ in his research, found that it is technically feasible to convert huge amount of cassava wastes into highly proteinous feeds for animals by introducing certain microorganism such as fungi. Cassava sieveates is converted to garri for man's use, while starch content is used as food for man and as gum. Unfermented cassava is converted to cassava flour as food for man. Cassava waste is enormous, it can be processed and converted into useful products such as methane (biogas), ethanol, surfactant, fertilizer and even feed for livestock. Already more than $80 \%$ of the cassava solid waste is being used productively, primarily as pig and fish feed and also for other innovative purposes in many countries ${ }^{16}$.

Table 5: Summary of Respondent's Response on Converting Cassava Wastes to Other Useful Products

\begin{tabular}{|c|c|c|c|}
\hline Respondents & $\begin{array}{c}\text { Cassava } \\
\text { wastes }\end{array}$ & $\begin{array}{c}\text { Conversion } \\
\text { process }\end{array}$ & $\begin{array}{c}\text { Secondary } \\
\text { beneficiary } \\
\text { products. }\end{array}$ \\
\hline 30 & $\begin{array}{c}\text { Cassava } \\
\text { peels }\end{array}$ & $\begin{array}{c}\text { Sun or air } \\
\text { dried } \\
\text { mixed with } \\
\text { animal feed }\end{array}$ & $\begin{array}{c}\text { Feed supplement } \\
\text { for animals }\end{array}$ \\
\hline & $\begin{array}{c}\text { Cassava } \\
\text { sieveates }\end{array}$ & $\begin{array}{c}\text { Ground } \\
\text { mixed with } \\
\text { poultry } \\
\text { freed }\end{array}$ & $\begin{array}{c}\text { Poultry feed (feed } \\
\text { supplement ) }\end{array}$ \\
\hline & $\begin{array}{c}\text { Starch } \\
\text { content }\end{array}$ & $\begin{array}{c}\text { Sieved and } \\
\text { allowed to } \\
\text { settle. }\end{array}$ & $\begin{array}{c}\text { Food for man and } \\
\text { domestic gum }\end{array}$ \\
\hline & $\begin{array}{c}\text { Unfermented } \\
\text { cassava }\end{array}$ & $\begin{array}{c}\text { Dried, } \\
\text { ground, } \\
\text { filter }\end{array}$ & $\begin{array}{c}\text { Cassava flour (food } \\
\text { for man ) }\end{array}$ \\
\hline
\end{tabular}

Source: Field Survey 2019

\section{Implications of the Study}

The practical implication of this study is that it has shown the state of cassava processing mills in Kwale.

The findings of this research will contribute to the knowledge of environmental science and waste management practice.

Since proper environmental management is needed for healthy living, the findings of this study will not only improve the aesthetic nature of Kwale's environment but also encourage healthy living. The study therefore recommends as follows:

- Education of cassava processors on Environmental management and laws concerning cassava waste disposal and pollution.

- Government assistance in waste disposal

- Localizing cassava processors in a particular area to minimize pollution

The study was limited by lack of finance due to visitation of the various locations to collect both information and materials. There was also some difficulties in extracting information, concerning cassava mills and its processing, even after explaining that it was for research purposes. Despite these limitations, however, the results obtained remains reliable and valid.

\section{CONCLUSION}

It can be concluded that Garri, Fufu, Starch, cassava flour and tapioca are the major products obtained from cassava. Cassava peels, cassava sieveates, cassava waste water, starch content and unfermented cassava are wastes obtained after getting the major products. The different disposal method for 
these wastes was also analyzed, its negative impact on the environment and how it can be converted to secondary beneficial products.

\section{ACKNOWLEDGEMENT}

The study team wishes to acknowledge the useful information provided by farmers, cassava processors, traders, input suppliers and other key informants at all the study locations in Kwale, their special input and their cordial and accommodative nature during the field work of this study are very much appreciated.

\section{Significance Statement}

This study discovers the true state of cassava processing mills in kwale, Niger Delta. The findings of this research will contribute to the knowledge of environmental science and waste management practice. Since proper environmental management is needed for healthy living, the findings of this study will not only improve the aesthetic nature of kwale environment but also encourage healthy living.

\section{RUNNING TITLE}

Waste Management in Cassava Processing Mill Industry

\section{AUTHOR CONTRIBUTION}

Peter M. Eguvbe designed the study while Salem Azagbaesuweli did the write up and research.

\section{CONFLICT OF INTEREST}

There is no conflict of interest.

\section{REFERENCES}

[1] Coulibaly, O., Arinloye, D.A.A, Faye, M. and Abdoulaye, T. 2014. Regional cassava value chains analysis in West Africa: Case study of Nigeria. DOI: 10.13140/2.1.3421.6001.

[2] Solomon, U.U. 2009. The state of solid waste management in Nigeria. J. Waste. Management (New York). 29(10):2787-8. https://www.ncbi.nim.nih.gov.DOI= 10.1016/j.wasman.2009.06.030.

[3] Olukanni, D.O., Agunwamba, J.C and Abalogu, R.U 2013 Interaction between suspended and settled solid particles in cassava waste water. Scientific Research and Essay, 8(10), 414424. https://academicjournals.org doi.org/10.5897/SRE12.658.
[4] Ogunbode, A.A, Akinosun, A.A. and Olajide,T.M. 2019. Nutrients and anti-nutrient content of sundried cassava starch extract pulp. J. Appl. Sc. Environ. Manage. 23(6).1133-1135. DOI: https://dx.doi.org/10.4314/jasem.v23i6.21.

[5] Alyson, L.P.R., Glouber, C., Maria, E.P.S. and Wohia, C.G. 2018. Application of cassava harvest residues (manihotesculentacrantz) in biochemical and thermochemical conversion process for bioenergy purposes: A literature review. Afr. J. Biotechnol. DOI: 10.5897/AJB. https://doi.org/10.5897/AJB2017.16322.

[6] Omilani, O. Adebayo, B.A. and Victor, O.O. 2019. Smallholder agroprocessors' willingness to pay for value-added solid waste management solutions. Sustainability. 11. 1759. www .mdpi.com/journal/sustainability.doi:10.3390/su110.61759.

[7] Kehinde, A.T. 2007. Utilization potentials of cassava in Nigeria: The domestic and industrial products. Food Reviews International. 22:1. 29-42. DOI: 10.1080/87559120500379787.

[8] Morrell, P.D. and Carroll, J. B. 2010. Conducting educational research: A primer for Teachers and Administrators. Bold Visions in Educational Research: Pioneers. 1.294. DOI: https://doi.org/10.1163/9789460912047.

[9] Izah S.C, Bassay S.E, Ohimain E.I 2018. Impacts of cassava mill effluents in Nigeria. Journal of Plant and Animal Ecology 1(1), 14, 2018. DOI $=10.14302 /$ issn.2637-6075.jpae-17-1890..

[10] Odediran, O.F., and Ojebiyi, W. G. 2017. Cassava processors' willingness to utilize cassava peel for mushroom production in Southwest Nigeria. Inter. J. Agric. Policy. Res. 5(4): 86-93. https://www.journalissues.org/IJAPR/ https://doi.org/10.15739/IJAPR.17.010.

[11] Burns, A., Gleadow, R., Cliff, J., Zacarias, A. and Cavagnaro, T. 2010. Cassava: The drought, war and famine crop in a changing $\begin{array}{lll}\text { world. } & \text { Sustainability. } & \text { 2(11): }\end{array}$ https://doi.org/10.3390/su2113572.

[12] Izah, S.C. 2018. Estimation of potential cassava mill effluents discharged into Nigerian environment. Environ. Anal. Eco. Stud.2(5). DOI: 10.31031/EAES.2018.02.000550.

[13] Izah, S.C., Bassey, S.E. and Ohimain, E.I. 2017. Changes in the treatment of some physicochemical properties of cassava mill effluents using Saccharomyces cerevisiae. Toxics. 5.28. www.mdpi.com/journal/toxics. DOI: 10.3390/toxics5040028.

[14] Adeyemo O K. 2005. Haemotological and Histopathological effects of cassava mill effluent in clariesgarienpinus, African journal of Biomedical Research vol 8 No 3 Pg 179-183. DOI: 10.4314/ajbr.v813.35747

[15] Obueh, H.O and Odesiri-Eruteyan, E. 2016. A study on the effects of cassava processing wastes on the soil environment of a local cassava mill, Journal of Pollution Effects \& Control, 4(4), 1-4. DOI: $10.4176 / 2375-4397.1000177$.

[16] Morgan, N.K. and Choct, M. 2016. Cassava: Nutrient composition and nutritive value in poultry diets. Anim. Nutr. 2(4):253-261. DOI: 10.1016/j.aninu.2016.08.010. 